\title{
Green technology to limit the effects of hexavalent chromium contaminated water bodies on public health and vegetation at industrial sites
}

\author{
Bikash Kumar Das ${ }^{1}$, Pratyush Kumar Das ${ }^{1}$, Bidyut Prava Das ${ }^{2}$, Patitapaban Dash ${ }^{1 *}$ \\ ${ }^{1}$ Centre for Biotechnology, Siksha 'O' Anusandhan (Deemed to be University), Bhubaneswar, Odisha, India. \\ ${ }^{2}$ Sailabala Women's Autonomous College, Cuttack, Odisha, India.
}

\begin{tabular}{ll}
\hline ARTICLE INFO & ABSTRACT \\
\cline { 2 - 3 } $\begin{array}{l}\text { Article history: } \\
\text { Received on: October 19, 2020 } \\
\text { Accepted on: December 05, } 2020 \\
\text { Available online: March 10,2021 }\end{array}$ & $\begin{array}{l}\text { The chromium is a heavy metal with wide industrial applications. It exists in the environment mostly in two stable } \\
\text { forms, relatively least toxic trivalent form, Cr(III) and highly toxic hexavalent form, Cr(VI). The release of this } \\
\text { hazardous Cr(VI) with effluents from industrial sites, at post-production stage, is the root cause of water pollution } \\
\text { across the globe. The Cr(VI) is one of the priority pollutant as per USEPA classification. It is mostly released with } \\
\text { anthropogenic activities such as mining, steel making, welding, tanning, textile dyeing, and wood polishing. Besides } \\
\text { other harmful features, it is considered as a proven human carcinogen. Its high toxicity can be attributed to its small } \\
\text { molecular size, ionic form, mobility, high solubility, and permeability. Exceeding the threshold limits, water bodies } \\
\text { Key words: } \\
\begin{array}{l}\text { Cnthropogenic, } \\
\text { Carcinogen, }\end{array}\end{array}$ \\
$\begin{array}{l}\text { Environment, } \\
\text { Remediation, } \\
\text { Toxic. }\end{array}$ & $\begin{array}{l}\text { Moreover, this study laid emphasis on the anthropogenic sources of release of Cr(VI) into the water bodies, its } \\
\text { adverse effects, and remediation of these emerging problems. The novelty of this study lies with the remediation of } \\
\text { contaminated water bodies with zero maintenance. It is preferable over other techniques on the basis of its cost of } \\
\text { operation, ease in application, and compatibility with the environment. }\end{array}$ \\
\hline
\end{tabular}

\section{INTRODUCTION}

The silver-gray colored chromium is a lustrous and abundant heavy metal. Its reactivity is high as compared to the other transition metals such as cadmium, lead, mercury, nickel, and copper. The enrichment of chromium in our environmental components is possibly linked with its wider application in multiple types of industrial activities [1]. From all the oxidation states of $\mathrm{Cr}$, the less reactive trivalent chromium, $\mathrm{Cr}(\mathrm{III})$ and highly reactive hexavalent chromium, $\mathrm{Cr}(\mathrm{VI})$ are comparatively stable. The $\mathrm{Cr}(\mathrm{VI})$ is treated as hazardous for the living biota. The $\mathrm{Cr}(\mathrm{VI})$ rich industrial effluents not only contaminating the surface water of water bodies but also pollutes the groundwater and soil to some extent due to leaching and percolations.

The water pollution by chromium is not only confined to freshwater, but it also contaminates the marine waters present in the oceanic bodies. The most promising way of chromium contamination of oceanic waters is through rivers. At the post-production stage, the $\mathrm{Cr}(\mathrm{VI})$ rich effluents generated from industrial activities such as production and finishing of metals, tanning of leather, production of cement are discharged into

*Corresponding Author

Patitapaban Dash,

Centre for Biotechnology, Siksha 'O' Anusandhan (Deemed to be University),

Bhubaneswar - 751003, Odisha, India.

E-mail: patitapabandash@soa.ac.in rivers and ultimately leads to river water pollution. The borewell water at Ahmedabad was also contaminated with chromium [2]. The study of K.R. Campbell in 1995 confirmed the Cr contamination of marine water. The costal seawater is also not being free from $\mathrm{Cr}$ contamination [3].

\section{CHROMIUM AS A POLLUTANT}

Out of all oxidation states of chromium, the stability is confined to the trivalent form, $\mathrm{Cr}$ (III) and the hexavalent form, $\mathrm{Cr}(\mathrm{VI})$. In addition to its relatively high stability in the environmental components, the $\mathrm{Cr}(\mathrm{VI})$ expresses high reactivity and eco-toxicity. Both these forms are inter-convertible with alterations in the physical and chemical parameters of the medium of its presence.

\subsection{Trivalent Chromium [Cr(III)]}

The Cr (III) is less soluble in water and less mobile in nature. The $\mathrm{Cr}(\mathrm{III})$ is toxic for the living systems only at high concentration. The presence of $\mathrm{Cr}(\mathrm{III})$ is well known in the effluents released from the units linked with the production or processing of metals, inks, dyes, pigments, glasses, leathers, wood preservatives, textile, and corrosion inhibitors [4]. The $\mathrm{Cr}(\mathrm{III})$ is essential in the diet of human-beings as it regulates the glucose metabolism in human body [5]. The $\mathrm{Cr}$ (III) is not toxic at low concentration, but with the increase in concentration, it shows its toxicity on plants and humans. 


\subsection{Hexavalent Chromium [Cr(VI)]}

The $\mathrm{Cr}(\mathrm{VI})$ is soluble in water and more toxic than $\mathrm{Cr}(\mathrm{III})$. Upon oxidation, $\mathrm{Cr}$ (III) gets converted to $\mathrm{Cr}(\mathrm{VI})$. Its oxy-anionic form makes it more soluble in water. The mobile $\mathrm{Cr}(\mathrm{VI})$ is highly toxic and treated as carcinogenic for total living systems.

\section{SOURCES OF RELEASE OF HEXAVALENT CHROMIUM [CR(VI)] AND WATER POLLUTION}

The chromites are the main source of elemental chromium. The pollution of water resources with $\mathrm{Cr}(\mathrm{VI})$ broadly occurs through two sources like natural and manmade [Figure 1]. The phosphate fertilizers, a manmade product, contain $30-3000 \mathrm{mg} \mathrm{kg}-1$ of $\mathrm{Cr}$ [6]. The anthropogenic sources are responsible for releasing $\mathrm{Cr}(\mathrm{VI})$ and/ or $\mathrm{Cr}$ (III) to the environment [Table 1] and are directly or indirectly involved with the pollution of water.

\section{FLUCTUATION OF HEXAVALENT CHROMIUM [CR(VI)] LEVEL IN WATER}

Regulatory bodies are considering the contribution of individual water quality parameters towards water quality standards and prescribing the threshold limits for water quality parameters. Based on its hazardous features, $\mathrm{Cr}(\mathrm{VI})$ has been identified as an "A" level carcinogen by the US Environmental Protection Agency [8].

The rainwater is not even spared from the contamination of chromium. $0.2-1 \mu \mathrm{g} \mathrm{L} \mathrm{L}^{-1}$ of $\mathrm{Cr}$ was present in the rainwater and up to $84 \mu \mathrm{g} \mathrm{L}^{-1}$ of $\mathrm{Cr}$ was recorded in surface water of the United States. Compared to it, the $\mathrm{Cr}$ content of the groundwater was $2-10 \mu \mathrm{g} \mathrm{L}^{-1}$. The drinking water supplied to the public at the US retained $<5 \mu \mathrm{g} \mathrm{L} \mathrm{L}^{-1}$ of $\mathrm{Cr}$ [9]. The recorded data are an image of variation in $\mathrm{Cr}$ content of types of water in our environment.

The study of the Central Leather Research Institute (CLRI), India, reported that more than 1500 metric tons of chromium sulfate per annum are discharged to the open environment. Kanpur in Uttar Pradesh of India is the hub of the textile and leather industries, which produces $\mathrm{Cr}$ wastes of more than 250 times of $0.05 \mathrm{ppm}$, the amount recommended by the WHO guidelines [10]. The solubility of $\mathrm{Cr}$ (III) depends on the $\mathrm{pH}$ of water. The concentration of the $\mathrm{Cr}$ (III) is $8 \mu \mathrm{g}$ $\mathrm{L}^{-1}$ and $\mathrm{Cr}(\mathrm{VI})$ is $5 \mu \mathrm{g} \mathrm{L}^{-1}$ in normal water [11].

The $\mathrm{Cr}$ concentration of drinking water in different countries is such as $15 \mu \mathrm{g} \mathrm{L}^{-1}$ at England, $0.2-2 \mu \mathrm{g} \mathrm{L}^{-1}$ in Canada, $<0.1 \mu \mathrm{g} \mathrm{L}{ }^{-1}$ at the UK, $1 \mu \mathrm{g} \mathrm{L}^{-1}$ in Netherland, and $<0.2 \mu \mathrm{g} \mathrm{L}^{-1}$ in India. The mean world average of $\mathrm{Cr}$ in drinking water is $0.5-7.5 \mu \mathrm{g} \mathrm{L}^{-1}$. Similarly, the mean range of $\mathrm{Cr}$ in rainwater is $0.2-<1 \mu \mathrm{g} \mathrm{\textrm {L } ^ { - 1 }}$ [12].

\section{MODE OF CONTAMINATION OF WATER BY HEXAVALENT CHROMIUM [CR(VI)]}

The $\mathrm{Cr}(\mathrm{VI})$ is hazardous and " $\mathrm{A}$ " level carcinogen. It is a metal with high solubility in water. It is generally found in the wastes from steel, tannery, and chemical industries. The high concentration and solubility makes $\mathrm{Cr}(\mathrm{VI})$ dangerous and provides the ability to contaminate the groundwater as well as surface water directly or indirectly. The $\mathrm{Cr}(\mathrm{VI})$ is more water-soluble and its mobility is high in nature as compared to $\mathrm{Cr}(\mathrm{III})$. The $\mathrm{Cr}(\mathrm{VI})$ has the ability to directly contaminate the groundwater through soil colloids.

In the primary level, the $\mathrm{Cr}$ (III) creates a strong bond on solid surface, but $\mathrm{Cr}(\mathrm{VI})$ remains dissolved in water for its chemical structure. The accumulation capacity in biological tissues is generally by the molecular size and shape of these $\mathrm{Cr}$ forms. In aquatic animals, the

Table 1: Mode of the release of chromium $(\mathrm{Cr})$ and water pollution.

\begin{tabular}{ll} 
Sources of release & Released Cr species \\
Burning of conventional fuel & $\mathrm{Cr}(\mathrm{III})$ \\
Production of stainless steel & $\mathrm{Cr}(\mathrm{III})$ and $\mathrm{Cr}(\mathrm{VI})$ \\
Production and use of chemicals & $\mathrm{Cr}(\mathrm{VI})$ \\
Electroplating & $\mathrm{Cr}(\mathrm{VI})$ \\
Tanning of leather & $\mathrm{Cr}(\mathrm{III})$ and $\mathrm{Cr}(\mathrm{VI})$ \\
Production and use of dyes and pigments & $\mathrm{Cr}(\mathrm{III})$ and $\mathrm{Cr}(\mathrm{VI})$ \\
Disposal of industrial wastes and coal ash & $\mathrm{Cr}(\mathrm{III})$ and $\mathrm{Cr}(\mathrm{VI})$ \\
\hline
\end{tabular}

Source [7]

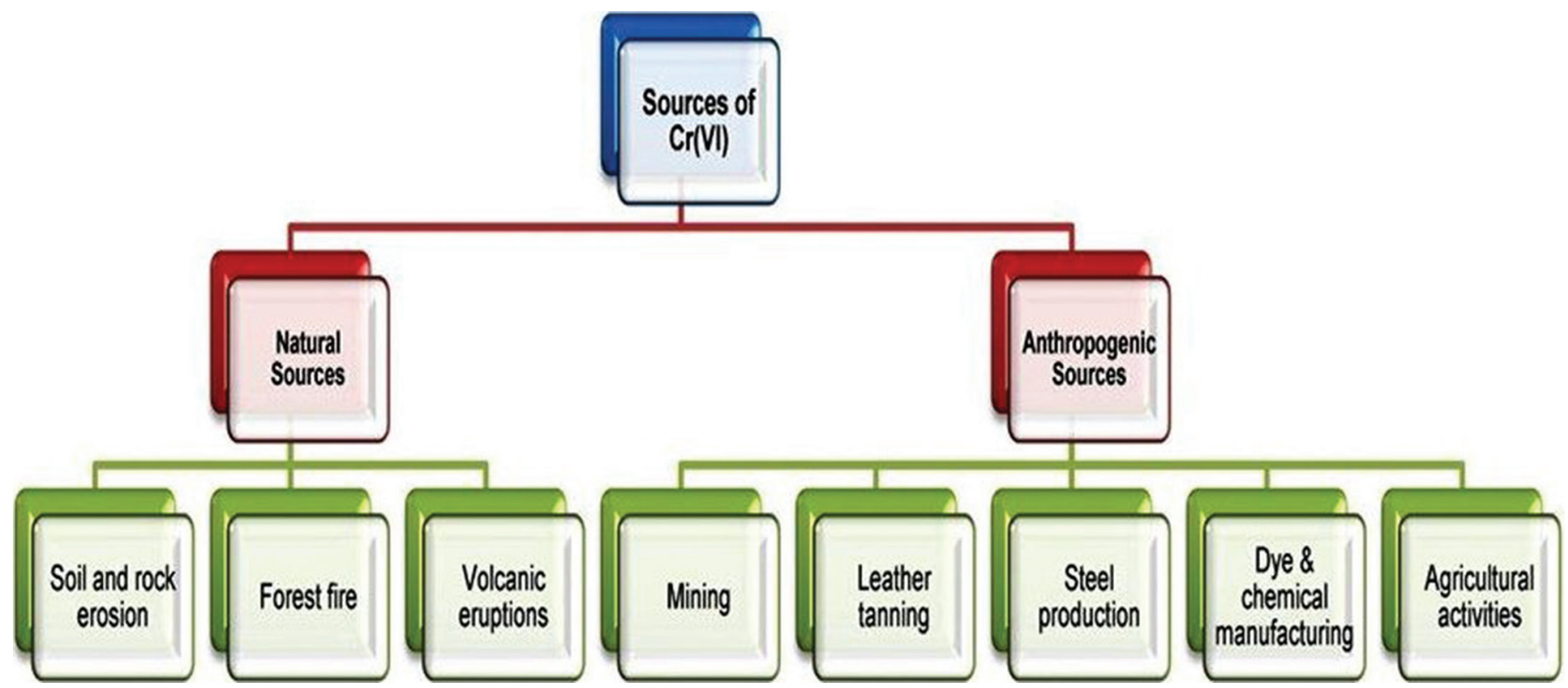

Figure 1: Sources of hexavalent chromium [Cr(VI)]. 
$\mathrm{Cr}(\mathrm{VI})$ is found in kidney, liver, and gill cells. In marine biota, the liver accumulates the highest concentration of metals. The biological systems in aquatic animals have the capacity to convert the toxic $\mathrm{Cr}(\mathrm{VI})$ to less toxic $\mathrm{Cr}(\mathrm{III})$. The high concentration of $\mathrm{Cr}(\mathrm{VI})$ in biological tissues creates the reductive condition and supports the conversion of $\mathrm{Cr}(\mathrm{VI})$ to $\mathrm{Cr}(\mathrm{III})$. The phytoplankton and algae present in marine ecosystems absorb the metals. The contaminants may be removed by dissolution, adsorption, and precipitation. In comparison to all the

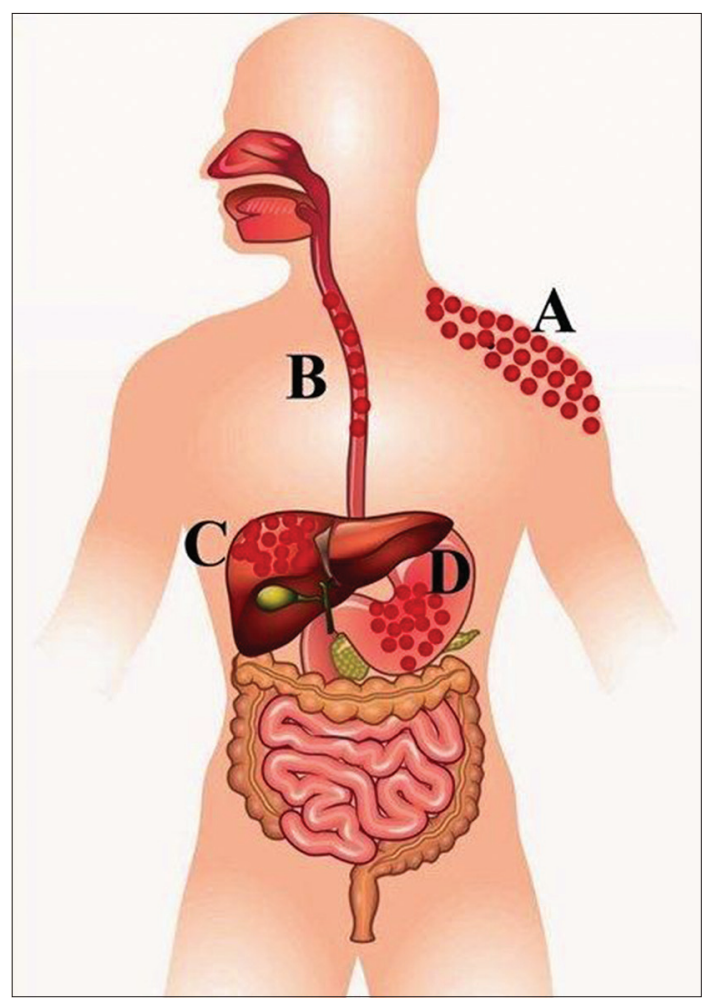

Figure 2: Effects of hexavalent chromium $[\mathrm{Cr}(\mathrm{VI})]$ on human body: A - skin, B - esophagus, C - liver, D - stomach. conventional methods of $\mathrm{Cr}$ removal, the biotechnological method is preferable as it is cost-effective and eco-friendly $[2,3]$.

\section{TOXICITY OF HEXAVALENT CHROMIUM [CR(VI)]}

Chromium is highly soluble and has high mobility in nature. Its high mobility increases the possibility of groundwater contamination. It has been studied that when the aquatic (fish) animals come in direct contact with $\mathrm{Cr}(\mathrm{VI})$, the concentration of atretic oocytes is increased and vitellogenin oocytes are decreased. The $\mathrm{Cr}$ is prominently available to living organisms through several ways such as consumption, epidermal adjoin, and adsorption in plants. The current section deals with the toxic impacts of $\mathrm{Cr}(\mathrm{VI})$ on humans health and plants.

\subsection{Effects on Human}

Chromium at low concentration is required as a nutrient for human metabolism. On a daily basis, $100 \mu \mathrm{g}$ of $\mathrm{Cr}$ can be consumed in the form of food. $\mathrm{Cr}$ is found to be present in certain foods such as potatoes, seafood, mushrooms, yolk of egg, and also in other types of vegetables and fruits [13]. Chromium is a very active element that plays a major role in body glucose tolerance and regulation of blood sugar. It also regulates the insulin level inside the body. On a daily basis, the Cr required for body metabolism is $<200 \mathrm{ug}$ and involves in body weight loss.

However, regular exposure of $\mathrm{Cr}(\mathrm{VI})$ imparts toxic effects on human health. Exposure of the respiratory system to $\mathrm{Cr}(\mathrm{VI})$ causes cancer [13]. The chromium directly affects human body and causes several diseases such as skin irritation, skin sensitization, allergy, mucosa membrane injury, and impairment of the liver, kidney, pulmonary function, creating tumors in stomach and decreasing the capacity of immune system [Figure 2]. $\mathrm{Cr}(\mathrm{VI})$ is mobilized into the human cell by anion carriers that resemble phosphate as well as sulfate. Through the sulfate transporter $\mathrm{Cr}(\mathrm{VI})$ easily penetrates to human blood cells as its mobility is high as compared to $\mathrm{Cr}(\mathrm{III})$. Inside the human cell, $\mathrm{Cr}(\mathrm{VI})$ reduces to $\mathrm{Cr}(\mathrm{III})$ by reaction with water $\left(\mathrm{H}_{2} \mathrm{O}\right)$, nitrogen nitrogen dioxide $\left(\mathrm{NO}_{2}\right), \mathrm{SH}_{4}$, and $\mathrm{Mg}$ to inflict cellular damage in the process

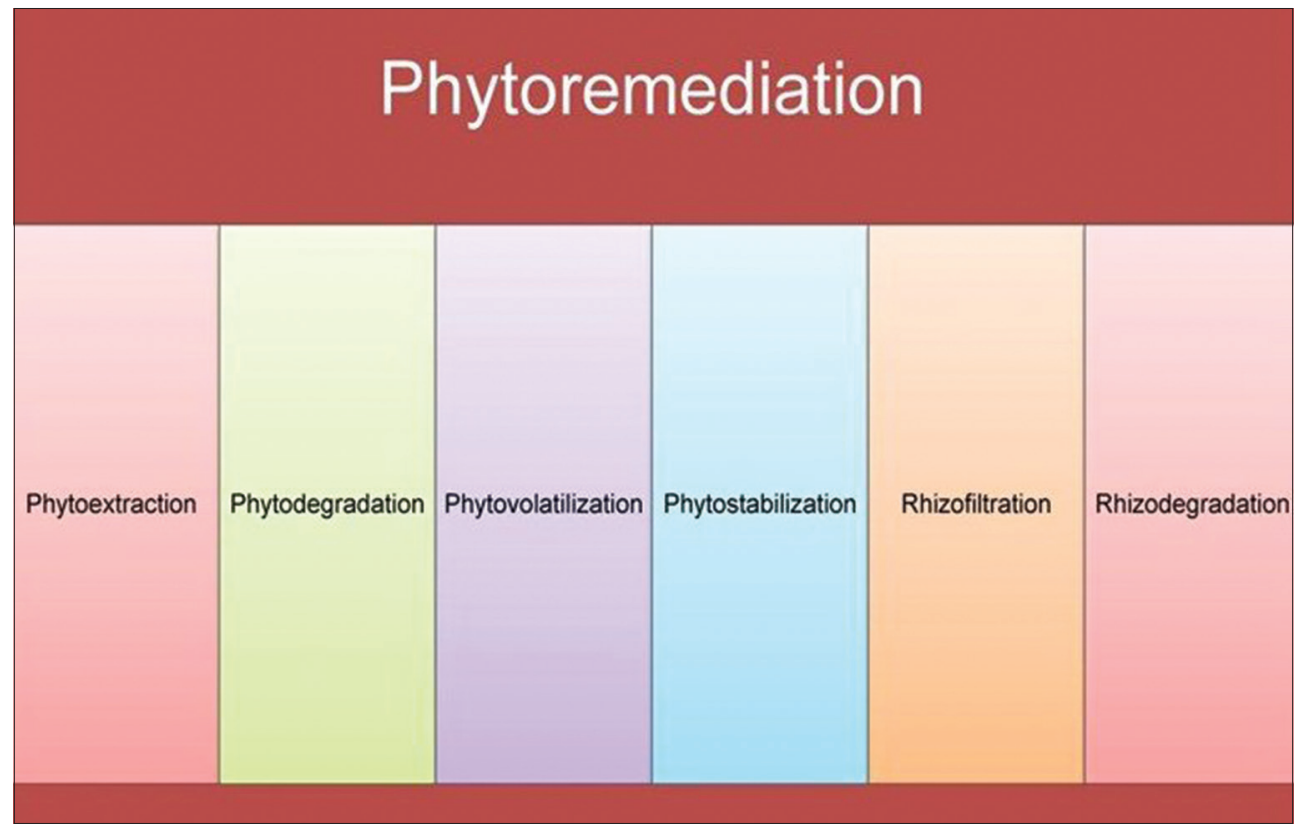

Figure 3: Types of phytoremediation techniques. 
[3]. The $\mathrm{Cr}(\mathrm{VI})$ binds to the double strands of DNA which impairs replication and repair of genes. It is easily transported through the cellular membrane and ultimately involved in the metabolic reduction in some cases. In some other cases, $\mathrm{Cr}(\mathrm{III})$ is oxidized to form $\mathrm{Cr}(\mathrm{VI})$, which creates toxic impacts [14].

The trivalent chromium also causes some allergic conditions, creating toxicity and genotoxicity for human beings. Both males and females were infected by $\mathrm{Cr}(\mathrm{VI})$, which leads to symptoms like lower abdominal pain, reduction in appetite, and diarrhea [10].

The Cr contaminated saliva goes to the gastrointestinal tract with food, then converts the $\mathrm{Cr}(\mathrm{VI})$ to $\mathrm{Cr}(\mathrm{III})$ by some chemical and absorption process. The rest excess $\mathrm{Cr}(\mathrm{VI})$ is easily absorbed by the vascular tray and processes with red blood cells [15]. Then, $\mathrm{Cr}$ binds to the blood plasma and finally spreads to the whole body. Sixty percent of $\mathrm{Cr}(\mathrm{VI})$ ion will be excreted by nails, hair, milk, sweat, and the rest amount of it form complex proteins by combining with primary proteins. Chromium directly comes in contact with human body by inhalation, ingestion, or skin contact and result in the increase of $\mathrm{Cr}$ in urine [16]. The chromium causes mutation to DNA by forming Cr-DNA conjugates, DNA-protein cross-linkage, and oxidative DNA damage. The $\mathrm{Cr}(\mathrm{VI})$ inhibits the tumor suppresser gene and facilitates the occurrence of cancer by methylation $[17,18]$. The $\mathrm{Cr}(\mathrm{VI})$ induces the blastogenesis in phyto-agglutinins in human lymphocytes. It mainly affects T-lymphocytes in human immune system. By the in vitro study, it has been seen that the $\mathrm{Cr}$ alloy particles induce the release of inflammatory mediated macrophages before cell death [19]. The $\mathrm{Cr}$ creates cytotoxic effects in cells. It has been shown that apoptosis is caused due to the presence of $\mathrm{Cr}(\mathrm{VI})$ and $\mathrm{Cr}(\mathrm{V})$. Exposure of $\mathrm{Cr}(\mathrm{VI})$ creates various point mutation in DNA and some chromosomal damages [17]. The $\mathrm{Cr}$ directly affects the respiratory tract and causes asthma, chronic bronchitis, chronic irritation, chronic pharyngitis, congestion, polyps in the upper respiratory tract, hyperemia, and trachea bronchitis like diseases. The $\mathrm{Cr}$ also has adverse impacts on human skin. This includes conditions such as dryness, erythroma, fissured skin papules, small vesicles, and swelling of skin layer. It also negatively affects the melanin and epidermal cell layer, thereby causing several types of allergies. The $\mathrm{Cr}(\mathrm{VI})$ also affects other parts of body such as kidney, liver, intestine, and cardiac muscles and causes growth problems and corneal injury.

\subsection{Effects on Plants}

In general, chromium compounds are very much reactive across plant physiology and metabolism. The $\mathrm{Cr}$ has no essential role to play in plant metabolism. Both $\mathrm{Cr}$ (III) and $\mathrm{Cr}$ (VI) have adversely affect the photosynthesis process, reduce chlorophyll, and inhibit plant growth. The $\mathrm{Cr}$ phytotoxicity is also involved in inhibition of seed germination, antioxidants, enzymes, induce oxidative stress, and degrade pigments status in plants. The phytotoxicity of both $\mathrm{Cr}$ (III) and $\mathrm{Cr}$ (VI) has been studied in many higher and lower plants. In low concentration, $\mathrm{Cr}$ (III) also affects growth, water balance, pigment content of the plant, and initiates lipid peroxidation. The $\mathrm{Cr}(\mathrm{VI})$ directly affects the leaves by reducing palisade and spongy parenchyma cells, increasing the number of vacuoles, and by interfering with electron density along with the walls of xylem and phloem. The Cr reacts with glutathione, nicotinamide adenine dinucleotide (NADH), and water, forming hydroxyl $\left(\mathrm{OH}^{-}\right)$radicals. The $\mathrm{Cr}$ leads to plasmolysis of the root cells. It induces the degradation of chlorophyll a and b, carotenoids, proteins, and reduces the nitrate [1]. It affects plant growth, causes chlorosis of new leaves, wilting of tops, distortion of photosynthesis, distortion of roots, and finally leads to plant death [20]. The Cr creates deleterious effects on plants such as disturbance in photosynthesis, reduction in nutrient assimilation, and imbalance in the enzymatic activities. It also causes damage to the cell membrane. Mainly, $\mathrm{Cr}$ moves through xylem of the plant and reduces the plant height. The trifoliate leaves are more affected by $\mathrm{Cr}$ than its primary leaves [21]. The mechanism behind plant uptake of $\mathrm{Cr}$ is not clearly understood till date. The uptake of $\mathrm{Cr}$ (III) by plant is a passive process. The $\mathrm{Cr}(\mathrm{VI})$ due to its high solubility is more toxic then $\mathrm{Cr}(\mathrm{III})$. The toxicity of $\mathrm{Cr}$ depends on metal speciation. It is toxic to agronomic plants at a concentration of $0.5-5.0 \mathrm{mg} \mu \mathrm{l}^{-1}$ in nutrient solution and $5-100 \mathrm{mg} \mathrm{g}^{-1}$ in soil [22]. Under normal condition, the concentration of $\mathrm{Cr}$ in plants is $<1 \mu \mathrm{g} \mathrm{g}^{-1}$. Accumulation of $\mathrm{Cr}$ in plants occurs in order of root $>$ stem $>$ leaves $>$ seed.

\section{PHYTOREMEDIATION AND REMOVAL OF HEXAVALENT CHROMIUM [CR(VI)] TOXICITY FROM CONTAMINATED ENVIRONMENTAL COMPONENTS}

The remediation of heavy metals from contaminated water is favored by roots of plants along with associated microbes. The $\mathrm{Cr}$ (VI) and $\mathrm{Cr}$ (III) cross the endodermis through symplast and the $\mathrm{Cr}$ (VI) is reduced to $\mathrm{Cr}$ (III). Compared to other parts, roots accumulate more $\mathrm{Cr}$ in plant. The mechanism behind this accumulation is the movement of $\mathrm{Cr}$ to xylem of plants. It helps to reduce the toxicity of the $\mathrm{Cr}$ in surroundings. It is a novel, effective, eco-friendly, and cost-effective technique for remediation of Cr. Now a day, scientists genetically modify the accumulation capacity of the plants for this purpose. This is a very well resultant application for remediation of large polluted aquatic area with low cost [23]. The accumulation of $\mathrm{Cr}(\mathrm{VI})$ by Black Gram (Vigna mungo) is an example in this context. Mainly, it has high capacity root and shoot systems for the accumulation of $\mathrm{Cr}(\mathrm{VI})$ and its enzymatic reduction to $\mathrm{Cr}$ (III) [5].

Out of the most reliable techniques for remediation, phytoremediation is one which is an emerging area of research. It has been applied to remove or accumulate heavy metals such as chromium $(\mathrm{Cr})$, lead $(\mathrm{Pb})$, and cadmium (Cd) from contaminated waters and soils using selected plants. Phytoremediation is advantageous as it is cost-effective, less time consuming, easy to understand, efficient, in situ applicable, and eco-friendly in nature. In addition to it, solar-driven potential makes it to be adjudged as the best possible route for the remediation of hexavalent chromium from environmental components [24].

Phytoremediation is an interdisciplinary process, as it is linked with ecology, soil chemistry, soil microbiology, plant biotechnology, and environmental engineering [25]. The mechanism of wilting and plasmolysis of root cells are mainly playing a key role to remove heavy metals from contaminated biota [5].

\subsection{Mechanism of Phytoremediation}

The uptake of $\mathrm{Cr}$ like $\mathrm{Cr}(\mathrm{III})$ is a passive process without loss of any energy. The plant accumulates metals through chelation with the proper high-affinity ligand, reduction, biotransformation, and compartmentalization in the plant cytoplasm. For $\mathrm{Cr}$ detoxification, the immobilization process in plant vacuoles is playing a major role. However, the uptake of $\mathrm{Cr}(\mathrm{VI})$ is comparatively complicated, active, and routed through sulfate or phosphate carriers [22].

The plants such as Polygonum coccineum, Brachiara mutica, and Cyprus papyrus have the potential to be used in the process of phytoremediation. It gives batter results to remove $\mathrm{Cr}(\mathrm{VI})$ from $\mathrm{Cr}$ contaminated water [4]. High $\mathrm{Cr}(\mathrm{VI})$ contents of the soil have the 
possibility to contaminate surface and groundwater resources [26]. Bamboo species available all over the world are a useful resource for phytoremediation as the plants can utilize $\mathrm{Cr}$ contaminated soil as growth factor. It is a possible step to minimize the $\mathrm{Cr}(\mathrm{VI})$ concentration from wastewater [19].

Multiple phytoremediation techniques [Figure 3] are available for hexavalent chromium remediation at contaminated sites. The removal of contaminants by plant parts is not a seasonal phenomenon. In addition, the growth of those plants on the contaminated crop field supplements certain secondary products to the local soil and helps in the pre-cultivation management of degraded soils. Many plant species of families Brassicaceae, Euphorbiaceae, Asteraceae, Lamiaceae, and Scrophulariceae are useful in this context [27,28].

The roots, shoots, and leaves of plants are playing an important role during phytoremediation of hexavalent chromium. The uptake and translocation of chromium by hyperaccumulators have the possibility of minimizing $\mathrm{Cr}(\mathrm{VI})$ in environmental components. The evaporation of water from leaves acting as a pump to absorb nutrients and heavy metals from root system [29]. The mechanism behind it is the mass flow of metals from soil to plant along the water potential gradient and from root to aerial plant parts through diffusion pressure deficits created by transpiration pull [24]. The root system channelizes the movement of heavy metals to aerial plant parts through xylem and ultimately mechanized to be deposited in the vacuoles of biological tissues having low metabolic activities. The surplus amount of heavy metals has the possibility to move on to cytosols. The regulatory molecules regulate its movement inside the plants [23].

\subsubsection{Phytoextraction (Vegetal assimilation)}

The heavy metals from soil or water are accumulated by selective plants. It is a feasible process and allows the harvesting of heavy metals from environmental components by the root biomass [23]. Phytoextraction depends on shoot metal concentration and shoot biomass. The capacity to accumulate heavy metals is positively correlated with the solubility of heavy metals [25]. Phytochelation and use of metallothionein are also helpful for phytoextraction [27].

\subsubsection{Phytofiltration (Rhizofiltration)}

It is the removal of heavy metals from surface water or wastewater by selected plant species. Mostly, roots are used for degradation of heavy metals [25]. It can remove metals from contaminants. The plants grown hydroponically in normal clean water at optimum temperature and $\mathrm{pH}$ favors the formation of a wide root system [27].

\subsubsection{Phytostabilization (Root stabilization)}

The plants stabilize and immobilize heavy metals by sorption, sedimentation, and complexation in rhizosphere [4,23]. The mobility and bioavailability are the most prominent phenomena in this process. It is not a suitable solution to remove heavy metals from soil [25].

\subsubsection{Phytovolatilization (Vegetal evaporation)}

The deep roots are playing a crucial role in this method. Mostly, it is applicable for groundwater remediation [23]. The disadvantages of this process include the transfer of contaminants from one environmental component to another, like its movement from soil to atmosphere.

\subsubsection{Phytodegradation (Organic degradation)}

It is a type of organic degradation of metals. It uses enzymes such as dehalogenation and oxygenation. It involves the plants having the potential to accumulate pollutants present in the environmental components. It is followed by the detoxification of those pollutants by metabolism of those plants. The positive aspects of this remediation technique include the dissolution of contaminants in the natural environment [27,29].

\subsubsection{Rhizodegradation (Use of rhizosphere for degradation)}

It utilizes the microorganisms present in the rhizosphere to breakdown the organic pollutants. The increase in the metabolism of the microbes enhances the degradation rate of pollutants in rhizosphere. Plants can stimulate the microbial activity in rhizosphere by $10-100$ times. It is possibly correlated with the release of phytoexudates rich in carbohydrates, amino acids, and flavonoids in rhizosphere [23].

\section{OTHER REGULATING PROCESSES}

The removal of chromium is essential for a healthy living world. It imparts a toxic effect on living organisms. There are several techniques for the removal and reduction of $\mathrm{Cr}(\mathrm{VI})$. However, some specific techniques are used more often to remediate the $\mathrm{Cr}$ from wastewater or drinking water. The authors detail about some of these techniques in the succeeding section.

\subsection{Reduction}

It is a technique where $\mathrm{Cr}(\mathrm{VI})$ reduces to $\mathrm{Cr}(\mathrm{III})$ by some chemical reactions. The sodium metal bisulfate is used for the reduction of $\mathrm{Cr}(\mathrm{VI})$ but is costly. Inside the cell, the $\mathrm{Cr}(\mathrm{VI})$ cannot be converted to $\mathrm{Cr}(\mathrm{III})$ as the toxicity is dependent on the concentration and temperature [22]. The chromium ion may be reduced in the presence of water $\left(\mathrm{H}_{2} \mathrm{O}\right)$, manganese $\left(\mathrm{Mn}_{2}\right)$, nitrogen dioxide $\left(\mathrm{NO}_{2}\right)$, iron $(\mathrm{Fe})$, sulfur $\left(\mathrm{S}_{2}\right)$, and methane $\left(\mathrm{CH}_{4}\right)$ like reducing agents. It can get oxidized with $\mathrm{O}_{2}, \mathrm{O}_{3}, \mathrm{Mn}(\mathrm{IV}), \mathrm{Fe}(\mathrm{II})$, and $\mathrm{CO}_{2}$ as an oxidizing agent.

The reduction process uses chemicals such as sulfuric acid $\left(\mathrm{H}_{2} \mathrm{SO}_{4}\right)$, sodium dithionate $\left(\mathrm{Na}_{2} \mathrm{~S}_{2} \mathrm{O}_{4}\right)$, and sodium hydroxide $(\mathrm{NaOH})$ with a settling tank. After the settlement of $\mathrm{Cr}$, the freshwater will be collected. Sulfide is playing a major role in this reduction process [30].

According to Birjand, the reduction mechanism of $\mathrm{Cr}(\mathrm{VI})$ of groundwater to $\mathrm{Cr}$ (III) occurred by the standard jar method using sulfur as a reducing agent. It also limes milk with ferrous sulfate. The concentration of $\mathrm{Cr}$ reduces to $0.015 \mathrm{mg} / \mathrm{l}$, which is much less than WHO guidelines of $0.05 \mathrm{mg} \mathrm{L}^{-1}$ [31].

\subsection{Nano-zerovalent Iron Technology (nZVI)}

First, the process was used at the USA and Europe for the purification of soil and groundwater. For the nZVI technology, the $\mathrm{pH}$ and dissolved oxygen (DO) acts as crucial factors, as DO enhance the removal of $\mathrm{Cr}(\mathrm{VI})$. The mechanism behind this involves adsorption and reducing ability [32]. Various techniques have been developed for the formation of nZVI such as thermal reduction of ferrous iron, electrolysis, and synthesis from polyphenolic plant extracts [33].

For wastewater management, the metallic iron or nano-zerovalent iron is highly useful. It works along the principles of correlations in between cathode and anode. Through the mechanism of both sorption and reduction, the metal can form "core cell" as it is occurring simultaneously [34]. Sepiolite supported nZVI is an adsorption and reduction based mechanism used for the reduction of $\mathrm{Cr}(\mathrm{VI})[17]$. Due to the hydrophilic nature, the chitosan is a good $\mathrm{Cr}$ adsorbent. It consists of amino acid groups and flexible structure of polymeric chain. The chemicals used in the process are quite expensive. The mechanism 
behind this is the physical adsorption and subsequent reduction of $\mathrm{Cr}(\mathrm{VI})$ to $\mathrm{Cr}(\mathrm{III})$ by nZVI. The efficiency of this technique can be analyzed by the utilization of the transmission electron microscope, $\mathrm{X}$-ray diffractometer, and photoelectron spectroscopy [27,35].

\subsection{Microbial Remediation}

Among all types of chromium reducing bacteria (CRB), the gram-positives are reactive against $\mathrm{Cr}(\mathrm{VI})$ and gram-negatives with $\mathrm{Cr}(\mathrm{III})$. Certain aerobic and non-aerobic bacteria such as Lactobacillus, Pseudomonas dichromate, and Aeromonas dichromate are more resistant against the toxicity of $\mathrm{Cr}$ and also reduce the $\mathrm{Cr}(\mathrm{VI})$ to $\mathrm{Cr}(\mathrm{III})$. Under anaerobic conditions, these microorganisms enhance the NADH activity, an enzyme cofactor. Aerobic bacteria are comfortable with soluble proteins, used as an electron donor for growth purpose. The anaerobic bacteria such as Escherichia coli, Ochrobactrum sp., and Providencia sp. pose frequent resistance against $\mathrm{Cr}(\mathrm{VI})[3,24]$. The $\mathrm{NADH}$ acts as an electron donor for the growth of microorganisms under anaerobic condition. The reduction achieved was found to be $30 \%$ in $1 \mathrm{~h}$ with $\mathrm{pH} 6$ and might take $6-8 \mathrm{~h}$ for $100 \%$ removal of $\mathrm{Cr}(\mathrm{VI})$. Lactobacillus acidophilus has the fastest working capacity for reduction of $\mathrm{Cr}(\mathrm{VI})$ to $\mathrm{Cr}(\mathrm{III})$ [36].

The reduction process of $\mathrm{Cr}(\mathrm{VI})$ has also been carried out by a novel yeast called Rhodotorula mucilaginosa. The peptone sucrose medium is playing an important role in this reduction process. These yeasts work very fast, as it has various respiration sites. The optimum $\mathrm{pH}$ is 5.5 and the temperature is $30^{\circ} \mathrm{C}$ for better result. At low $\mathrm{pH}$, the cell wall functional groups are protonated and work towards metal binding [37]. The Penicillium oxalicum performs a crucial role in the bioreactor to reduce the toxicity of $\mathrm{Cr}(\mathrm{VI})$ [38].

Besides the processes discussed, there are other processes like use of melanin embedded beads to remove the $\mathrm{Cr}$. The $\mathrm{Cr}(\mathrm{VI})$ can be removed by the use of isolated melanin bead (IMB) originated from squid ink sac and commercial melanin beads (CMB) originated from sesame seeds. The FTIR analysis supported the effectiveness of the process [15].

Palygorskite contains a large active hydroxyl group on the surface area. It is more effective and beneficial for $\mathrm{Cr}(\mathrm{VI})$ adsorption from the aqueous solutions [39]. The use of neem leaves as a biosorbent removes $85 \%$ of the $\mathrm{Cr}(\mathrm{VI})$ from drinking water and also from other aqueous solutions [40]. The novel cellulose hydrogel coating with $\mathrm{Fe}^{0}$ nanoparticles are utilized against $\mathrm{Cr}(\mathrm{VI})$ in the aquatic environment. It is $35 \%$ effective, but the high cost is a constraint for the success of this process [41].

The chitosan charcoal composite is used as a $\mathrm{Cr}(\mathrm{VI})$ remover from the aqueous solution. It contains ceramic coating, forming a whitecolored stable granular composite biosorbent. The adsorption rate is high due to its more active sites for $\mathrm{Cr}(\mathrm{VI})$ [42]. The bone charcoal acts as a $\mathrm{Cr}(\mathrm{VI})$ remover. It depends on the prevailing $\mathrm{pH}$, concentration, and sample volume. However, only $47 \%$ of $\mathrm{Cr}$ can be removed by this process [43]. The $\mathrm{Cr}$ can be adsorbed by bamboo waste and chemically activated carbon. It can records up to $98.39 \%$ accumulation capacity [44]. The hydroponic technique using plants such as Thlaspi, Brassica, Sedum, and Arabidopsis species is more suitable for the phytoremediation process. The Brassicaceae species are mostly used for the accumulation of heavy metals such as zinc ( $\mathrm{Zn})$ and cadmium (Cd). The $\mathrm{Cr}(\mathrm{VI})$ is reduced to $\mathrm{Cr}(\mathrm{III})$ by reducing agents such as sulfur- and iron-based salts at acidic $\mathrm{pH}$. The $\mathrm{Cr}$ can be removed by nanotechnology from industrial effluents [45]. The Cr(III) enters into the cell by passive diffusion and phagocytosis [46]. Membrane filter technique is suitable for the treatment of $\mathrm{Cr}(\mathrm{VI})$ contaminated wastewater. There are types of membrane filtration processes such as inorganic, polymeric, and liquid membrane-based. The techniques based on the inorganic membrane are effective techniques with high thermal stability $[16,47]$.

\section{ADVANTAGES OF PHYTOREMEDIATION OVER OTHER TECHNIQUES}

Phytoremediation utilizes macrophytes which play a promising role in the remediation of hexavalent chromium [48]. Phytoremediation has several advantages over other conventional techniques. This includes cost-effective operation and maintenance, ease of monitoring the process, eco-friendly nature, and the least possibility of any secondary pollution arising out of it. Moreover, this technique neither involves any energy inputs nor requires any skilled manpower for its successful operations.

\section{CRITERIA FOR SELECTION OF PLANTS FOR PHYTOREMEDIATION}

Phytoremediation is carried out by plants that are referred to as hyperaccumulators. Every plant does not possess the characteristics of a hyperaccumulator and therefore cannot successfully remediate water contaminated with $\mathrm{Cr}(\mathrm{VI})$. Selection of suitable plant is one of the most important aspects for the phytoremediation of $\mathrm{Cr}(\mathrm{VI})$ contaminated water bodies. Selection of plants for phytoremediation should be based upon certain specific criteria such as wide availability, level of $\mathrm{Cr}(\mathrm{VI})$ tolerance, rate of biomass production, ability to grow under varied climatic conditions, temperature fluctuations, and nutrient concentration. The rate of extraction of metal like $\mathrm{Cr}(\mathrm{VI})$ by the plant is also an important factor in the selection process [30] and is governed by the root system of hyperaccumulator plants. Plants with a large area of branched root networks and long taproot system are always a better choice for the purpose of phytoremediation.

\section{CONCLUSION}

The chromium is one of the toxic heavy metals used widely during production and post-production stages. It is released from industries along with generated wastes. The chromium contamination of environmental components is an emerging problem and exhibits an increasing trend of contaminations in many countries with a change in lifestyle pattern and industrialization. The purpose of this present study is to improve the remediation of chromium contaminated water bodies. It may lead to reduce the direct and indirect toxic effects of this heavy metal on public health and vegetation at contaminated sites. The removal of chromium by physical and chemical methods has certain limitations. The major limitations include its application at the field scale level and the cost incurred during the operation of the remediation process. The novelty of this study lies with the immobilization of this mobile pollutant in specified zones of the environment to protect the aquatic environment from further degradation. The suitability of phytoremediation is useful in this context. Its cost-effectiveness and zero maintenance make this technique preferable over other techniques. Further study in this area of study is highly solicited to improve the efficiency of this process of remediation of $\mathrm{Cr}(\mathrm{VI})$ contaminated water bodies.

\section{CONFLICTS OF INTEREST}

The authors declare no conflict of interest 


\section{REFERENCES}

1. Panda SK, Choudhury S. Chromium toxicity in plants. Braz J Plant Physiol 2005; 17:95-102.

2. Zaidi S, Panchal M, Parekh V, Shaikh A, Zaidi U, Desai U, et al. Ground water contamination with hexavalent chromium and its health effects: Debatable and unsettled issue of regulation. 2010;2020:300-10.

3. Sarker BC. Chromium effects of tannery waste water and appraisal of toxicity strength reduction and alternative treatment. Int J Agron Agric Res 2013;3:23-35.

4. Kassaye G, Gabbiye N, Alemu A. Phytoremediation of chromium from tannery wastewater using local plant species. Water Pract Technol 2017;12:894-901.

5. Saravanana A, Jayasreea R, Hemavathya RV, Jeevananthama S, Hamsinia S, Kumarb PS, et al. Phytoremediation of $\mathrm{Cr}(\mathrm{VI})$ ion contaminated soil using Black gram (Vigna mungo): Assessment of removal capacity. J Environ Chem Eng 2019;7:103052.

6. Nandi R, Saha B. Sources and toxicity of hexavalent chromium. J Coord Chem 2011;64:1782-806.

7. Alka B, Madhurima P, Kant PP. A review of Hexavelent chromium contamination in India. Res J Chem Sci 2017;7:39-44.

8. United States Environmental Protection Agency. Integrated Risk Information System (IRIS) on Chromium VI. National Center for Environmental Assessment. Washington, DC: Office of Research and Development; 1999.

9. World Health Organization. WHO World Health Survey. Geneva: World Health Organization; 2003. Available from: http://www3.who. int/whs.

10. Sharma P, Bihari V, Agarwal SK, Verma V, Kesavachandran CN, Pangtey BS, et al. Groundwater contaminated with hexavalent chromium [Cr (VI)]: A health survey and clinical examination of community inhabitants (Kanpur, India). PLoS One 2012;7:e47877.

11. Oliveira H. Chromium as an environmental pollutant: Insights on induced plant toxicity. J Bot 2012;2012:375843.

12. World Health Organization. Guidelines for Drinking-water Quality Chromium in Drinking-water. Geneva: World Health Organization; 2019.

13. Budiawan B, Auerkari EL. Effects of Chromium on Human Body. Research Gate, No. 317403540; 2017.

14. Das AP, Mishra S. National institute of technology, Rourkela, Orissa, hexavalent chromium (VI): Environment pollutant and health hazard. J Environ Res Dev 2017;2:386-92.

15. Hany OE, Neelam A, Alamgir A, Kanwal H. Determination of chromium in the tannery wastewater, Korangi, Karachi. Int J Environ Sci Nat Res 2018;15:122-5.

16. Cuong AM, Thi Le Na N, Thang PN, Diep TN, Thuy LB, Thanh NL, et al. Melanin-embedded materials effectively remove hexavalent chromium (CrVI) from aqueous solution. Environ Health Prevent Med 2018;23:9.

17. Shrivastava R, Upreti RK, Seth PK, Chaturvedi UC. Effects of chromium on the immune system. FEMS Immunol Med Microbiol 2002;34:1-7.

18. Ortega R, Fayard B, Salome M, Deve G, Susini J. Chromium oxidation state imaging in mammalian cells exposed in vitro to soluble or particulate chromate compounds. Am Chem Soc 2005;2005:7245588.

19. Were FH, Wafula GA, Wairungu S. Phytoremediation using bamboo to reduce the risk of chromium exposure from a contaminated tannery site in Kenya. J Health Pollut 2017;7:12-25.

20. Mathur S, Kalajih M, Jajoo A. Investigation of deleterious effects of chromium phytotoxicity and photosynthesis in wheat plant. Photosynthetica 2016;54:185-92.

21. Zhang XH, Liu J, Huang HT, Chen J, Zhu YN, Wang DQ. Chromium accumulation by the hyperaccumulator plant Leersia hexandra
Swartz. Chemosphere 2007;67:1138-43.

22. Das PK, Das BP, Dash P. Chromite mining pollution, environmental impact, toxicity and phytoremediation: A review. Environ Chem Lett 2020;2020:226.

23. Ali H, Khan E, Sajad MA. Phytoremediation of heavy metals concepts and applications. Chemosphere 2013;91:869-81.

24. Sumiahadi A, Acar R. A review of phytoremediation technology: Heavy metals uptake by plants. Earth Environ Sci 2018;142:12023.

25. Lone MI, He ZL. Stoffella PJ, Yang XE. Phytoremediation of heavy metal polluted soils and water. Univ Sci B 2008;9:210-20.

26. Das PK, Das BP, Dash P. Role of plant species as hyper-accumulators in the decontamination of hexavalent chromium contaminated soil. Indian J Environ Prot 2018;38:1016-24.

27. Adiloğlu S. Heavy metal removal with phytoremediatio. J Zhejiang Univ Sci B 2008;2008:70330.

28. Ahalya N, Ramachandra TV. Phytoremediation: Processes and mechanisms. J Ecobiol 2006;18:33-8.

29. Tangahu BV, Abdullah MR, Basri H, Idris M, Anuar N, Mukhlisin M. A review on heavy metals $(\mathrm{As}, \mathrm{Pb}$, and $\mathrm{Hg}$ ) uptake by plants through phytoremediation. Int J Chem Eng 2011;2011:939161.

30. Muthusaravanan S, Sivarajasekar N, Vivek JS, Paramasivan T, Naushad M, Prakashmaran J, et al. Phytoremediation of heavy metals: Mechanisms, methods and enhancements. Environ Chem Lett 2018;16:1339-59.

31. Heydarzadeh R, Ghadimkhani AA, Torabian A. An improvement of $\mathrm{Cr}+6$ removal by the reduction to $\mathrm{Cr}+3$ in Birjand ground water treatment. WIT Trans Ecol Environ 2006;95:201.

32. Fan Z, Zhang Q, Gao B, Li M, Liu C, Qiu Y. Removal of hexavelent chromium by biochar supported nZVI composite: Batch and fixedbed column evaluations, mechanisms, and secondary contamination prevention. Chemosphere 2018;217:85-94.

33. Chen Y, An D, Sun S, Qian JG. Reduction and removal of chromium VI in water by powdered activated carbon. Materials 2018;11:269.

34. Sen S, Shah P. Application of nanoscale zero-valent iron for wastewater treatment. Int Conf Multidiscip Res Pract 1986;1:2321-705.

35. Jang MH, Lim M, Hwang YS. Potential environmental implications of nanoscale zero-valent iron particles for environmental remediation. Environ Health Toxicol 2014;29:e2014022.

36. Mishra R, Sinha V, Kannan A, Upreti RK. Reduction of chromiumVI by chromium resistant lactobacilli: A prospective bacterium for bioremediation. Toxicol Int 2012;19:25-30.

37. Chatterjee S, Chatterjee NC, Dutta S. Bioreduction of chromium (VI) to chromium (III) by a novel yeast strai Rhodotorula mucilaginosa (MTCC 9315). Afr J Biotechnol 2012;11:14920-9.

38. Long B, Ye J, Ye Z, He J, Luo Y, Zhao Y, et al. Cr(VI) removal by Penicillium oxalicum SL2: Reduction with acidic metabolites and form transformation in the mycelium. Chemosphere 2020;253:126731.

39. Wang J, Sun T, Saleem A, Chen Y. Enhanced adsorptive removal of $\mathrm{Cr}(\mathrm{VI})$ in aqueous solution by polyethyleneimine modified Palygorskite. Chin J Chem Eng 2020;253:126731.

40. Joshi R, Raut S, Kulkarni S, Pande SD. Wastewater treatment for chromium removal: A review. Int J Sci Eng Technol Res 2014;3:2633-5.

41. Wang Y, Yu L, Wang R, Wang Y, Zhang X. A novel cellulose hydrogel coating with nanoscale $\mathrm{Fe} 0$ for $\mathrm{Cr}(\mathrm{VI})$ adsorption and reduction. Sci Total Environ 2020;726:138625.

42. Boddu V, Abburi K, Bott J, Smith E. Removal of hexavalent chromium from wastewater using a new composite chitosan biosorbent. Environ Sci Technol 2003;37:4449-56.

43. Dahbi S, Azzi M, Guardia MD. Removal of hexavalent chromium from wastewaters by bone charcoal. Fresenius J Anal Chem 1999;363:404-7. 
44. Siraj K, Kitte SA. Adsorption of hexavalent chromium from aqueous solution using chemically activated carbon prepared from locally available waste of bamboo (Oxytenanthera abyssinica). Int Sch Res Notices 2014;2014:438245.

45. Bezza FA, Chirwa EM. Production, Application of Zero Valent Iron Nanoparticles (nZVI) as Adsorbent for Removal of Chromium (VI) from Wastewater and Adsorption Studies. Conference Water Environment Federation Technical Exposition and Conference; 2018.

46. Jahan MA, Akhtar N, Khan NM, Roy CK, Islam R, Nurunnabi M. Characterization of tannery wastewater and its treatment by aquatic microphytes and algae. Bangladesh J Sci Ind Res 2014;49:233-42.
47. Owlad M, Aroua MK, Ashri W, Daud W, Baroutian S. Removal of hexavalent chromium-contaminated water and wastewater: A review. Water Air Soil Pollut 2009;200:59-77.

48. Das PK, Das BP, Dash P. Hexavalent chromium induced toxicity and its remediation using macrophytes. Pollut Res 2017;36:92-8.

\section{How to cite this article:}

Das BK, Das PK, Das BP, Dash P. Green technology to limit the effects

of hexavalent chromium contaminated water bodies on public health and

vegetation at industrial sites. J App Biol Biotech. 2021;9(2):28-35.

DOI: $10.7324 / \mathrm{JABB} .2021 .9203$ 